\title{
Jak dalece możemy naturalizować filozofię praktyczną?
}

\section{Gerhard Seel (Neuchâtel - Bern)}

Zanim jeszcze Quine został prorokiem naturalizmu (Quine, illness 1969a, s. 83; 1969b, ss. 26-127), na gruncie filozofii analitycznej do dobrego tonu należało ?naturalizowanie? wszelkich możliwych dziedzin filozofii: starano się zamienić je w domenę przyrodoznawstwa, a przede wszystkim ? w domenę empiryzmu. Odnosiło się to także do filozofii praktycznej. Taki rozwój wydarzeń zaskakuje o tyle, o ile anglosascy fundatorzy filozofii analitycznej, tj. Russell (1966, s. 21) i Moore (1960, ss. 910) zdecydowanie sprzeciwiali się naturalizowaniu filozofii praktycznej. Chciałbym tutaj pokazać, że filozofii praktycznej nie da się znaturalizować całkowicie, a dokładniej: że filozofia praktyczna nie ma racji bytu bez minimalnej choćby resztki transcendentalizmu.

Poniższe badania podzielę na trzy etapy. (1) W pierwszym etapie określę moją metodę badawczą i typologię argumentów, którymi będę się posługiwał. (2) W drugim etapie sprecyzuję, co rozumiem przez ?naturalizm praktyczny?. (3) W trzecim etapie pokażę, że naturalizm praktyczny prowadzi do nieskończonego regresu, jeśli przyjmie postać radykalną. Aby uniknąć regresu, musimy przyjąć, że obowiązują pewne pryncypia fundamentalne, które nie podlegają dalej naturalizacji.

\section{Etap pierwszy}

Jak wynika z debaty nad ostatecznym uprawomocnieniem zasad praktycznych, przypisujemy często nadmierną wagę argumentom transcendentalnym. Argumenty te są wprawdzie ważne i użyteczne, ale nie są w stanie dostarczyć ostatecznego uprawomocnienia. Proponuję więc ograniczyć ich używanie. Kiedy coś odrzucam, ma to swoją cenę: muszę bowiem zrezygnować ze stosowania określonych wyrażeń. Rezygnacji takiej można wymagać zgodnie z następującą zasadą:

wyrażenia resp. twierdzenia, dla których nie sposób wskazać żadnej akceptowalnej semantyki, albo takie, które dają się sprowadzić do innych wyrażeń, nie mają prawa obywatelstwa w danym języku. Jeśli próba dostarczenia takiej semantyki wykaże, że można je zachować tylko pod warunkiem subiektywnego uznania ich mocy obowiązującej, to wszyscy użytkownicy języka stoją przed taką oto alternatywą: albo twierdzenia te zaakceptować, albo zrezygnować z używania języka.

Zgodnie z tą zasadą moim celem jest postawić naturalistów praktycznych przed alternatywą: albo uznaje się pewne pryncypia transcendentalne, albo rezygnuje się z piętnowania innych ludzi za ich decyzje i działania, z pociągania ich do odpowiedzialności itd. Nie chodzi o żadne ostateczne uprawomocnienie tych pryncypiów, lecz tylko o wyjaśnienie: ?Jakie są warunki możliwości danego modusu działania językowego?? Wszak pytanie o warunki możliwości określonego typu ludzkiej praktyki ? czy będzie to poznanie i nauka, czy prawo i moralność ? należy do dobrej, transcendentalnej tradycji.

\section{Etap drugi}

Przechodzę teraz do drugiego pytania: czym jest naturalizm praktyczny? Pojęcie ?naturalizm? w interesującym nas tu znaczeniu pochodzi od G.E. Moore?a (1960, s. 37). Przez ?etykę naturalistyczną? rozumiał on teorię, wedle której termin ?dobry? (i w ogóle terminy praktyczne) daje się zdefiniować przez takie terminy (lub koniunkcję terminów), których prawdziwość wykazać można empirycznie, tzn. w drodze doświadczenia (por. Moore, 1960, ss. 38-39). R. M. Hare (1972, s. 82, 92) używa jednak pojęcia ?naturalizm? w szerszym znaczeniu. Nazywa ?naturalistycznymi? takie teorie etyczne, które definiują terminy praktyczne za pomocą koniunkcji terminów deskryptywnych. To, czy terminy deskryptywne są, czy nie są terminami empirycznymi, nie odgrywa tutaj roli. Pojęcie ?naturalistyczny? w szerokim sensie oznaczałoby raczej sposób definiowania w ogóle. W pierwszym punkcie chciałbym zatem objaśnić termin ?naturalizm? w szerokim sensie Hare?a. Poczynając od punktu trzeciego, będę go jednak używał w znaczeniu węższym, właściwym Moore?owi. Naturalizm Moore?a będzie z kolei przedmiotem mojej krytyki w ostatnim punkcie.

Aby pojąć, jakie znaczenie Hare przypisał wyrażeniu ?naturalizm?, wypada najpierw wiedzieć, po czym rozpoznajemy wyrażenia praktyczne i teoretyczne, a także: na czym polega syntaktyczna i semantyczna różnica między nimi. Jednak na gruncie języka naturalnego jest rzeczą trudną, a nawet zgoła niemożliwą przeprowadzenie wyraźnej granicy między wyrażeniami deskryptywnymi i praktycznymi. Z tej przyczyny Warnock (1967; 1974, s. 341) określił założenie antynaturalizmu - a implicite także naturalizmu - jako ?czysty nonsens?. Jednak filozofowie, którzy podobnie jak on uznają debatę o naturalizmie za bezprzedmiotową, tkwią w błędzie. Wprawdzie słusznie dostrzegają, że naturalizm i antynaturalizm nie są w stanie określić swych założeń precyzyjnie, jednak wyciągają stąd fałszywe wnioski: że założeń tych nie da się w ogóle określić. Proponuję poniżej sposób pozwalające określić te założenia dla pewnego typu języków sztucznych.

Aby tego dokonać, muszę najpierw wykazać, na czym polega różnica między językami teoretycznymi i praktycznymi. Różnicę tę widać najpierw na poziomie odmiennego znaczenia i posługiwania się tymi językami. Twierdzenia teoretyczne mówią o tym, że stany rzeczy zachodzą lub nie zachodzą. Wypowiedź (twierdzenie) teoretyczne rozumiemy wtedy i tylko wtedy, gdy dowiadujemy się z niego, że coś zachodzi lub nie zachodzi. 
Dla odmiany, twierdzenia praktyczne ? o tyle, o ile mogą przedkładać podmiotowi do wyboru alternatywy decyzji ? wyróżniają pewne stany rzeczy jako te, które mogą albo powinny być przedmiotem wyboru (na zasadzie przyzwolenia lub powinności). Rozumiemy twierdzenie praktyczne $a$ wtedy i tylko wtedy, gdy ? po pierwsze ? możemy stwierdzić (w granicach możliwości), czy znajdujemy się w sytuacji decyzyjnej podpadającej pod $a$, i gdy ? po drugie ? dowiadujemy się z niego, że powinniśmy w tej sytuacji podjąć decyzję zgodną z $a$. Innymi słowy, dowiadujemy się z takiego twierdzenia, jaką decyzję musimy podjąć, aby postąpić zgodnie z a (w sprawie sytuacji i procesów decyzyjnych zob. Seel, 1977, ss. 115-123; 1989, ss. 149-158). Zgadzam się więc z Hare?em, gdy powiada, że twierdzenia praktyczne są co do swej istoty kryteriami rozstrzygającymi (Hare, 1972, s. 20, ss. 127$150)$.

By móc pełnić właściwą im funkcję, języki teoretyczne muszą być wyposażone w dwa rodzaje wyrażeń: a) wyrażenia pozwalające dokładnie opisać stany rzeczy; b) wyrażenia pozwalające stwierdzić zachodzenie bądź niezachodzenie jakichś stanów rzeczy. Dla odmiany, języki praktycznezawierać muszą dodatkowo wyrażenia pozwalające wyróżnić jakiś stan rzeczy jako taki, który może lub powinien być przedmiotem wyboru resp. decyzji. Jako już powiedziano, na gruncie języków naturalnych trudno wyraźnie rozgraniczyć wyrażenia należące do jednej lub drugiej z tych klas. Poniżej chciałbym wskazać rodzaj języka sztucznego, gdzie rozgraniczenie takie można przeprowadzić zawsze.

Weźmy w tym celu sztuczny język teoretyczny o symbolu Lt1. W języku tym wyrażenia ?p?, ?q?, ?v?itp. oznaczają każdorazowo określony stan rzeczy. Wyrażenie ?T? symbolizuje operator: ?Jest tak, że...?. Na tej podstawie możemy zbudować twierdzenie $T p$.

Aby zbudować twierdzenie praktyczne, potrzebujemy dodatkowego operatora, którego nie ma w języku Lt1. Weźmy język praktyczny o symbolu $L p 1$, który oprócz wyrażeń języka $L t 1$ zawiera też wyrażenie $S T$, oznaczające operator obowiązywania, tj. ?Powinno być tak, że...?. W języku tym możemy zbudować twierdzenie praktyczne $S T p$ (czyt. ?Powinno być tak, że..."). Dla sztucznego języka Lp1 zaproponować możemy następujące kryterium syntaktyczne:

Wyrażenie $L p 1$ jest wyrażeniem praktycznym wtedy i tylko wtedy, gdy jest ono operatorem praktycznym lub zawiera operator praktyczny 1

Najpierwsza konkluzja wypływająca z tych rozważań jest taka: sztuczne języki praktyczne są w rzeczywistości rozszerzonymi językami teoretycznymi. Nie rozgraniczamy zatem sztywno jednych i drugich języków, lecz przyjmujemy, że dla każdego języka praktycznego istnieje dokładnie jeden język teoretyczny, którego rozszerzeniem jest ten tenże język praktyczny. Język teoretyczny może mieć przy tym więcej rozszerzeń praktycznych, ponieważ można go rozbudować na więcej sposobów. Jest przy tym oczywiste, że języki teoretyczne zawierają tylko twierdzenia teoretyczne, tymczasem języki praktyczne ? zarówno twierdzenia teoretyczne (deskryptywne), jak i twierdzenia praktyczne (preskryptywne).

W wyjaśnieniu pojęcia ?naturalizm? centralny udział przypadnie dalszym wynikom naszych badań. Istnieją najwyraźniej dwie klasy wyrażeń: a) takie, które występują w języku praktycznym i teoretycznym; b) takie, które występują wyłącznie w języku praktycznym i stanowią rozszerzenie języka teoretycznego do języka praktycznego. W przypadku języków sztucznych (oznaczonego wyżej typu) naturalizm praktyczny charakteryzuje takie oto założenie:

Dla wszystkich języków praktycznych jest tak, że wszystkie wyrażenia praktyczne tych języków mają przynajmniej jeden odpowiednik w wyrażeniu teoretycznym, mającym takie samo znaczenie.

Jeżeli założenie to jest trafne, to ? jak łatwo dostrzec ? każde twierdzenie praktyczne danego języka praktycznego Lp1 ma swój znaczeniowy odpowiednik w twierdzeniu teoretycznym języka $L t 1$, którego jest rozszerzeniem jest $L p 1$. Stąd też przez ?naturalizm? możemy rozumieć ogólne stanowisko, które ująć można w następującej definicji2:

Dla wszystkich języków praktycznych $x$ oraz wszystkich twierdzeń praktycznych vistnieje w odnośnym języku teoretycznym $y$ co najmniej jedno twierdzenie teoretyczne $v$ ? tego rodzaju, że znaczenia $v$ i $v$ ? się pokrywają.

$\forall \mathrm{x} \forall \mathrm{y} \forall \mathrm{v} \exists \mathrm{v}$ ? [(vSx ? xEy) $\rightarrow(\mathrm{v}$ ?Sy ? vBv?)]

Nietrudno dostrzec, że zdefiniowany w ten sposób naturalizm implikuje to, że w żadnym sztucznym języku praktycznym typu Lp1 nie można zbudować twierdzeń, które mogłyby odgrywać rolę kryteriów rozstrzygających. Uważam, że w językach tych nie da się wyartykułować próśb, poleceń ani rozkazów. Jest to podstawowa słabość tej wersji naturalizmu. Jej przeciwnicy ? trafnie, jak sądzę ? podnosili argument, że gdyby stanowisko to było słuszne, to musielibyśmy zrezygnować z pewnego typu aktów językowych, takich, jak właśnie prośby, polecenia i rozkazy (Hare, 1972, s. 84: ?thus if we accept the definition w debar ourselves from saying something that we do sometimes want to say.?)

Nie jest tak, że nasze zadanie badawcze nie ma nic wspólnego z językami naturalnymi. Wyjaśnijmy: nie wszystkie sztuczne języki są w pełni autonomiczne wobec języków naturalnych. Język sztuczny jest często generowany z języka naturalnego po to, by uniknąć wieloznaczności właściwych temu ostatniemu: prowadzą one bowiem do nieporozumień. Zaproponowałem wyżej pewien typ języków sztucznych, umożliwiający klasyfikację wyrażeń językowych do dwóch kategorii: teoretycznej i praktycznej. Nie upieram się przy tym, że podział taki jest niemożliwy dla języków naturalnych. Na poziomie wypowiedzi (?token?) podział ten jest przejrzysty. Ponieważ jednak w językach naturalnych używać można tego samego typu wyrażeń zarówno do budowy 
wypowiedzi praktycznych, jak i wypowiedzi teoretycznych, różnica praktyczny/teoretyczny nie ma tutaj sensu. Aby przywrócić jej ważność, wprowadziłem sztuczne reguły, które dzięki dodaniu stosownego operatora umożliwiają budowanie wyrażeń praktycznych z takich, które pierwotnie miały charakter czysto teoretyczny. Przy wprowadzaniu sztucznych wyrażeń należy jednak pilnie uważać, by to, co daje się wyartykułować w języku naturalnym (i co często rodzi nieporozumienia) dawało się wyartykułować w języku sztucznym bez żadnego uszczerbku dla sensu wypowiedzi (Hare?a ?model analityczny?, 1972, s. 180). Pod tym warunkiem możemy przyjąć, że ustalenia dotyczące języka sztucznego zachowują ważność także dla języków naturalnych.

Mamy tu pierwszy przykład zastosowania zarysowanej wyżej, transcendentalnej strategii argumentacyjnej: nie obaliliśmy naturalizmu, lecz postawiliśmy naturalistom alternatywę: albo zrezygnują z naturalistycznej semantyki, albo zaprzestaną określonego typu wypowiedzi. Nie mam w tym przedmiocie nic więcej do dodania i uważam dyskusję nad tą wersją naturalizmu praktycznego za zamkniętą. Jaki sens ma bowiem dalsze rozważanie możliwości i granic naturalizowania filozofii praktycznej?

Argumenty wytoczone przez przeciwników naturalizmu praktycznego (w tej skądinąd już historycznej debacie) można więc uznać za przekonujące i podjąć kolejną próbę wprowadzenia naturalizmu na wyższym poziomie. W rzeczy samej, przed kilkoma laty znów próbowano naturalizować filozofię praktyczną: próby te okazały się odporne na argumenty Hare?a. Ich zwolennicy, zamiast definiować obiektywne wyrażenia językowe takie jak ?dobry? i ?należy?, starają się definiować wyrażenia metajęzykowe w rodzaju ?moc obowiązywania? i ?obowiązujący? w terminach języka teoretycznego. Definicje takie nie zmuszają prima facie do rezygnacji z takich aktów językowych, jak prośba, polecenie, rozkaz itd. Obok starego, poczciwego naturalizmu praktycznego (nazwijmy go naturalizmem I stopnia) pojawił się zatem naturalizm nowej generacji (naturalizm II stopnia), który nieświadomie zmierza do dawnego celu, używając jedynie nowych środków. Naturalizm ten nie został jeszcze w najmniejszym stopniu przezwyciężony. Zajmę się tą nową odmianą naturalizmu w kolejnym etapie rozważań.

\section{Etap trzeci}

Na czym z grubsza polega naturalizm II stopnia i czym różni się od naturalizmu I stopnia? By odpowiedzieć na to pytanie, musimy najpierw wyjaśnić, co mamy na myśli, przypisując lub odmawiając danemu twierdzeniu (zbudowanemu w języku praktycznym) ważności i posługując się w tym celu wyrażeniami typu ?posiadający moc obowiązywania? lub ?obowiązujący?. Innymi słowy, musimy tu wprowadzić podstawy semantyki metajęzyka praktycznego. Niech posłuży nam za przewodnik poniższy podział, zawierający możliwe do utrzymania i faktycznie zajmowane stanowiska filozofii praktycznej.

\author{
naturalizm praktyczny I stopnia \\ Wszystkie twierdzenia praktyczne dają się \\ zredukować do twierdzeń teoretycznych. \\ subiektywizm praktyczny \\ Twierdzenia praktyczne nie różniq się moca \\ obowiazywania. \\ realizm praktyczny \\ Twierdzenia praktyczne sq prawdziwe lub fałszywe.
}

praktyczny naturalizm II stopnia

Praktyczne obowiązywanie nie zależy od najwyższych pryncypiów praktycznych, lecz wyłącznie od faktów.

\author{
antynaturalizm praktyczny I stopnia \\ Istnieją twierdzenia, które nie dajq̨ się zredukować do \\ twierdzeń teoretycznych.
}

obiektywizm praktyczny

Twierdzenia praktyczne różnią się moca

obowiązywania.

\section{antyrealizm praktyczny}

Twierdzenia praktycznie nie sq ani fatszywe, ani prawdziwe. Ich moc obowiązywania ma całkiem odmienna formę.

praktyczny antynaturalizm II stopnia

Praktyczne obowiązywanie zależne jest nie tylko od

faktów, lecz także od najwyższych zasad

praktycznych.

\section{Naturalizm praktyczny I stopnia ? antynaturalizm praktyczny I stopnia}

Jak widzieliśmy wyżej, w odniesieniu do sztucznych języków wskazanego typu naturalizm praktyczny I stopnia scharakteryzować można następująco:

Dla wszystkich twierdzeń praktycznych $v$ w każdym języku praktycznym $x$ istnieje w odnośnym języku teoretycznym $y$ co najmniej jedno twierdzenie teoretyczne $v$ ? tego rodzaju, że $v$ i $v$ ? znaczą to samo.

(NI) $\forall \mathrm{x} \forall \mathrm{y} \forall \mathrm{v} \exists \mathrm{v}$ ? [(vSx ? xEy) $\rightarrow(\mathrm{v}$ ?Sy ? vBv?)]

Oto negacja tej tezy: 
(ANIa) $\exists \mathrm{x} \exists \mathrm{y} \exists \mathrm{v} \forall \mathrm{v}$ ? [vSx ? $\mathrm{xEy}$ ? (v?Sy $\rightarrow \sim \mathrm{vBv}$ ?)]

Jednakże ta względnie słaba teza zwykle nie zadowala antynaturalistów. Zastąpmy ją zatem tezą mocniejszą, która nie jest kontradyktoryczna wobec naturalizmu I stopnia, lecz stanowi jego antytezę:

Dla żadnego twierdzenia praktycznego $v$ w jakimkolwiek języku praktycznym $x$ nie istnieje twierdzenie teoretyczne $v$ ? $\mathrm{w}$ odnośnym języku teoretycznym $y$ tego rodzaju, że $v$ i $v$ ? znaczą to samo3.

(ANIb) $\forall x \forall y \forall v \forall v$ ? [(vSx ? xEy ? v? Sy) $\rightarrow \sim \mathrm{vBv}$ ?]

\section{Subiektywizm praktyczny ? obiektywizm praktyczny}

Subiektywizm i obiektywizm praktyczny podzielają tezę ANIb, odpowiadając jednak na pytanie, czy twierdzenia praktyczne różnią się pod względem ważności, w odmienny sposób. Subiektywista praktyczny4 odrzuca twierdzenie, jakoby dla twierdzeń praktycznych istniało coś, co nadaje lub odbiera im moc obowiązywania, jak to się dzieje w przypadku prawdziwości twierdzeń teoretycznych. W jego przekonaniu bowiem twierdzenia te wyrażają wyłącznie subiektywne odczucia, życzenia, zamiary itp. żywione przez ich autora. Subiektywizm praktyczny scharakteryzować możemy poprzez koniunkcję następujących tez:

(ANIb) $\forall \mathrm{x} \forall \mathrm{y} \forall \mathrm{v} \forall \mathrm{v}$ ? [(vSx ? $\mathrm{xEy}$ ? v?Sy) $\rightarrow \sim \mathrm{vBv}$ ?]

(S) $\forall \mathrm{x} \forall \mathrm{u}[\mathrm{uSx} \rightarrow \sim \mathrm{uDx}]$

Należy sobie przy tym zdawać sprawę, że zwolennicy tego stanowiska ? zgodnie z naszym pryncypium metodologicznym ? muszą zaprzestać rozliczania kogokolwiek z zachowania lub działania. Kwalifikacje takie zakładałyby bowiem istnienie odpowiedzialności oraz norm o obiektywnej mocy obowiązywania. Jeśli ktoś nie jest gotów do takich wyrzeczeń, musi zaakceptować stanowisko obiektywizmu praktycznego. Zakłada ono, że nie tylko twierdzenia teoretyczne, ale i praktyczne mogą się różnić mocą obowiązywania, toteż do każdego języka zawierającego takie twierdzenia możemy wprowadzić metajęzyk pozwalający przypisywać lub odmawiać mocy obowiązywania tymże twierdzeniom. Obiektywizm praktyczny da się zatem scharakteryzować przez dwie następujące tezy:

(ANIb) $\forall \mathrm{x} \forall \mathrm{y} \forall \mathrm{v} \forall \mathrm{v}$ ? [(vSx ? $\mathrm{xEy}$ ? v?Sy) $\rightarrow \sim \mathrm{vBv}$ ?]

(O) $\exists x \exists u[u S x ? u D x]$

\section{Realizm praktyczny? antyrealizm praktyczny}

Realizm i antyrealizm praktyczny są formami, które przyjąć może obiektywizm praktyczny. Większość filozofów uważa jednak, że obiektywizm praktyczny możliwy jest tylko w formie realizmu praktycznego: utożsamiają oni obydwa te stanowiska. Na tym etapie naszego wywodu trzeba zatem wykazać, że w grę wchodzi jeszcze inna forma obiektywizmu praktycznego. Najpierw jednak określmy bliżej, na czym polega realizm praktyczny.

Otóż realiści praktyczni przyjmują, że jedyne kryteria różnicowania mocy obowiązywania twierdzeń praktycznych wyrażone są w wartościach teoretycznych takich, jak ?prawda? i ?fałsz?. Dlatego też utrzymują oni, że twierdzenia praktyczne o różnej mocy obowiązywania funkcjonują analogicznie do twierdzeń teoretycznych. Realizm praktyczny możemy więc scharakteryzować przez pomocy trzech następujących tez:

(ANIb) $\forall \mathrm{x} \forall \mathrm{y} \forall \mathrm{v} \forall \mathrm{v}$ ? [(vSx ? $\mathrm{xEy}$ ? v?Sy) $\rightarrow \sim \mathrm{vBv}$ ?]

(O) $\exists \mathrm{x} \exists \mathrm{u}[\mathrm{uSx}$ ? Du]

(R) $\forall \mathrm{x} \forall \mathrm{y}[(\mathrm{vSx} ? \mathrm{vDx} ? \mathrm{vFx}) \rightarrow \sim \mathrm{vWx}]$

Trzeba jednak zapytać, czy $R$ da się pogodzić z $A N I b . R$ byłoby sprzeczne z ANIb wtedy, gdyby prawdziwość lub fałszywość twierdzenia praktycznego zależała od tego, czy jego znaczenie jest równoważne znaczeniu odnośnego twierdzenia teoretycznego. Jeśli tak, to stanowisko realizmu praktycznego ? zgodnie z naszą definicją ? zawiera sprzeczność wewnętrzną. Teoria zawierająca jako tezy fundamentalne $O$ i $R$ musiałaby przyjmować $N I$ i stanowiłaby formę praktycznego naturalizmu I stopnia.

O tym, że nie wchodzi to w grę, możemy się przekonać rozważając (wzorem praktycznych realistów), co takiego czyni twierdzenie praktyczne prawdziwym lub fałszywym. Nie chodzi tu o fakt teoretyczny, lecz o tzw. fakt moralny (moral fact), a ponieważ fakty moralne nie dają się sprowadzić do faktów teoretycznych, $O$ i $R$ nie mogą implikować NI. Objaśnijmy to, posługując się konwencją Tarskiego (T). Powiada ona, że

?Tp? jest prawdziwe wtw, gdy Tp

Zgodnie z konwencją $T$ tym, co czyni dowolne twierdzenie teoretyczne prawdziwym, jest fakt stwierdzony przez wyrażenie umieszczone po prawej stronie oznaczenia ?wtedy i tylko wtedy?5. Jak widzimy, wyrażenie to nie zawiera ani operatora 
obowiązywania, ani żadnego innego wyrażenia praktycznego. Jeśli w analogii do konwencji $T$ chcielibyśmy zaproponować konwencję o prawdziwości twierdzeń praktycznych o formule $S T p$, to musi ona zakładać, że

\section{?STp? jest prawdziwe wtw, gdy STp}

Obecnie wyrażenie stojące po prawej stronie oznaczenia ?wtedy i tylko wtedy? zawiera operator obowiązku. Realiści praktyczni chcący zachować stanowisko antynaturalistyczne nie mogą zgodzić się na to, aby po prawej stronie oznaczenia ?wtedy i tylko wtedy? nie występowało żadne wyrażenie praktyczne. Według nich muszą tutaj stać wyrażenia stwierdzające fakty moralne. Przykładowo, fakt moralny jest faktem tego rodzaju, że zachodzić powinien dany stan rzeczy, albo: że dany świat jest lepszy od wszystkich innych światów. Tego rodzaju fakty twierdzić można wyłącznie dzięki zastosowaniu wyrażeń praktycznych. Dlatego właśnie faktów tych nie sposób sprowadzić do faktów teoretycznych. Zatem realiści praktyczni będą twierdzili, że tylko fakty moralne nadają prawdziwość twierdzeniom praktycznym: pozwala im to przyjąć $A N I b$.

W interesujący sposób, zgodnie z podanym wyjaśnieniem, także ?semantyki lepszych światów? podpadają pod realizm praktyczny. Za przykład niech posłuży definicja predykatu ?prawdziwe w świecie $w$ ?, która w naszej notacji brzmi tak:

?STp? jest prawdziwe w świecie $w$ wtedy i tylko wtedy, gdy $\exists$ w? (w? $\in$ BEST $\rightarrow$ ?Tp? jest prawdziwe w obrębie $w$ ?) $[w=$ świat $]$

O podpadaniu tego stanowiska pod realizm praktyczny decyduje okoliczność, że w wyrażeniu stojącym po prawej stronie oznaczenia ?wtedy i tylko wtedy? użyto predykatu ?BEST? (= najlepszy). Predykat ten jest wyrażeniem praktycznym, a opisywany przez niego fakt jest faktem moralnym.

Przeciwko realizmowi praktycznemu trzy kontrargumenty sformułował Mackie (1977):

(1) Gdyby istniały fakty moralne, to byłyby one faktami nadzwyczajnymi, zasadniczo odmiennymi od wszelkich innych faktów (Mackie, 1977: s. 38).

(2) Aby poznać te fakty, musielibyśmy dysponować nadzwyczajnymi zdolnościami poznawczymi. Taki sposób poznania byłby całkowicie odmienny od wszelkich innych sposobów poznania (tamże, ss. 38-39).

(3) Gdyby istniały fakty moralne, to wśród podmiotów musiałyby panować zgoda co do ich istnienia. W rzeczywistości jednak między podmiotami sądów praktycznych zachodzą drastyczne różnice (tamże, ss. 36-38).

Przeciwko tym jakoby niepodważalnym argumentom szereg zarzutów podnieśli obrońcy praktycznego realizmu (por. Brink, 1989): nie będę ich tutaj szczegółowo omawiał. W moim przekonaniu argumenty Mackiego ? mimo, że nie podważają wszystkich odmian praktycznego realizmu ? są na tyle ważkie, że realizm ten musi upaść, skoro tylko znaleziona zostanie spójna, alternatywna forma obiektywizmu praktycznego. Zwolennicy obiektywizmu nie atakują praktycznego realizmu tylko dlatego, że jak dotąd nikt jeszcze takiej alternatywy nie zaproponowal.

Ci, którzy z jednej strony obstają przy praktycznym obiektywizmie, a z drugiej ? podważają praktyczny realizm (mam na myśli zwolenników praktycznego antyrealizmu) powinni twierdzić, że istnieje przynajmniej jeden język praktyczny zawierający co najmniej jedno twierdzenie praktyczne, którego moc obowiązywania może być różna i jako taka nie ma nic wspólnego z prawdą i fałszem. Antyrealizm praktyczny scharakteryzować możemy za pomocą trzech następujących twierdzeńó

(ANIb) $\forall \mathrm{x} \forall \mathrm{y} \forall \mathrm{v} \forall \mathrm{v}$ ? [(vSx ? $\mathrm{xEy}$ ? $\left.\mathrm{v}^{\wedge} \mathrm{Sy}\right) \rightarrow \sim \mathrm{vBv}$ ?]

(O) $\exists x \exists u[u S x$ ? uDx]

(AR) $\exists \mathrm{x} \exists \mathrm{v}[\mathrm{vSx} ? \mathrm{vDx} ? \sim \mathrm{vFx} ? \sim \mathrm{vWx}]$

$A R$ jest do przyjęcia tylko wtedy, gdy obok metajęzykowych predykatów ?prawdziwy? (=W) i ?fałszywy? (=F) występują inne metajęzykowe predykaty, pozwalające przypisać lub odmówić twierdzeniom mocy obowiązywania. Oczywiście realiści praktyczni to wszystko odrzucą (por. Moore, 1960; Brink, 1989, ss. 14?23), powołując się przy tym na dwa argumenty o różnej mocy. Powiadają oni, że:

(1) W żadnym istniejącym metajęzyku obok predykatów metajęzykowych ?prawdziwy? i ?fałszywy? nie istnieją inne predykaty, za pomocą których można by przypisywać lub odmawiać ważności twierdzeniom praktycznym.

(2) Z powodów zasadniczych predykaty takie nie mogą istnieć.

Opierając się na pierwszym argumencie, realiści praktyczni wskazują, że celem przypisania lub odmówienia twierdzeniom praktycznym ważności stosuje się najczęściej predykaty ?prawdziwy? i ?fałszywy?, i że również na gruncie filozofii ? i to już od czasów Antyku ? żadne inne predykaty ważności nie były brane pod uwagę. Broniąc drugiej tezy (2), przywołują oni argument, że można stworzyć niesprzeczną i akceptowalną semantykę tylko dla wyrażeń ?prawdziwy? i ?fałszywy?. 
Aby bronić antynaturalizmu praktycznego przed tego typu zarzutami i utrzymać możliwość takiego stanowiska, należałoby pokazać, że istnieje pojęcie mocy obowiązywania (ważności) różne od pojęcia prawdy, dla którego można rozwinąć spójną i przejrzystą semantykę. Aby tego dokonać, chciałbym ponownie nawiązać do tego, co powiedziałem na początku o funkcji twierdzeń (zasad) praktycznych (por. Seel, 1982, ss. 610-612). Twierdzenie praktyczne $a$ pełni taką funkcję, że wskazuje podmiotowi decyzyjnemu znajdującemu się w sytuacji decyzyjnej podpadającej pod $a$ właściwą decyzję. Moim zdaniem twierdzenia praktyczne pełnią bowiem rolę kryteriów rozstrzygających. Zakładamy przy tym, że podmiot decyzyjny może w sposób dowolny wybrać takie lub inne alternatywne rozstrzygnięcie. Jeśli zdarzyłoby się tak, że podmiot decyzyjny mający na uwadze twierdzenie $a$ i znajdujący się w sytuacji decyzyjnej podpadającej pod $a$ musiał podjąć decyzję wyznaczoną przez kryterium $a$ (zakładając, że nie miał na uwadze żadnych innych kryteriów opozycyjnych do $a$ ), to nie byłby on wtedy wolny. Zakładam bowiem, że wolność decyzji polega na tym, iż podmiot decyzyjny mający na uwadze twierdzenie $a$ i znajdujący się w sytuacji decyzyjnej podpadającej pod $a$ dysponuje wolnym wyborem co do zastosowania lub niezastosowania $a$. Zakładam tym samym, że ten oto, konkretny wybór jest poprzedzony metawyborem, w ramach którego podmiot dokonać może wyboru między zastosowaniem bądź niezastosowaniem kryterium rozstrzygającego $a$, które ma na uwadze. Rodzi się tutaj pytanie, czy również dla takiego metawyboru może istnieć kryterium (twierdzenie praktyczne) podpowiadające podmiotowi decyzji, którą z alternatyw metawyboru powinien wybrać? Odpowiedź jest pozytywna. Mogę bowiem w metajęzyku Lp2, będącym rozszerzeniem Lp1 i posiadającym odpowiednie predykaty, zbudować takie oto twierdzenie:

F5: ?w sytuacji decyzyjnej podpadającej pod $a$ podmiot decyzyjny, który ma na myśli $a$ i świadomy jest tego, że znajduje się w sytuacji podpadającej pod $a$, powinien zastosować $a$.

Jest rzeczą oczywistą, że twierdzenie $F_{5}$ może być zastosowane pod warunkiem, że jest znane podmiotowi decyzji i że podmiot ten zdaje sobie sprawę z tego, że znalazł się w metasytuacji decyzyjnej podpadającej pod $F_{5}$.

Na podstawie tego wywodu wyprowadzić możemy konwencję $G$ odnoszącą się do obowiązywania twierdzenia praktycznego $a$ :

?a posiada moc obowiązującą w każdej sytuacji wtedy i tylko wtedy, gdy podmiot decyzyjny ma na myśli $a$ i zdaje sobie sprawę z tego, że znajdując się w sytuacji podpadającej pod $a$, powinien zastosować $a$.?

Wskażę teraz krótko na różnice, jakie zachodzą między konwencją $T$ a moją konwencją $G$ :

(1) Podczas gdy w konwencji $T$ na prawo od oznaczenia ?wtedy i tylko wtedy? znajduje się twierdzenie języka obiektywnego, przełożone jednorodnie na metajęzyk, konwencja $G$ zawiera po obu stronach tego samego oznaczenia twierdzenie praktyczne.

(2) Dlatego też konwencja $G$ ? w odróżnieniu od konwencji $T$ ? może być wprowadzona do semantycznej definicji metajęzykowego predykatu ?obowiązujący?. Definiens zawiera wyłącznie wyrażenia, które zastosowaliśmy w wyjaśnieniu funkcji kryteriów rozstrzygających dla procesu decyzyjnego. Ponieważ użytkownikowi języka $L p 1$ znane jest znaczenie operatora obowiązku i ponieważ wie on, co znaczy stosować twierdzenie zawierające taki operator, to nietrudno będzie wyjaśnić temu użytkownikowi także znaczenie metajęzykowego predykatu ?należy zastosować kryterium rozstrzygające $v$ ?, a także przybliżyć mu znaczenie metajęzykowego operatora ważności, który stanowi analogon operatora obowiązywania na gruncie języka przedmiotowego. Dzięki takiemu rozszerzeniu języka $L p 1$ do postaci $L p 2$ możemy zdefiniować metajęzykowy predykat ?jest ważny w języku Lp1? w taki oto sposób:

F7: Dla wszystkich v z vSLp1 (vGLp1 $\leftrightarrow$ dfSTAv)

Z definicji tej wynika, że twierdzenia metajęzykowe pozwalające przypisać moc obowiązywania twierdzeniom praktycznym na poziomie języka przedmiotowego są twierdzeniami praktycznymi, a nie teoretycznymi. Pełnią one funkcję kryteriów rozstrzygających na poziomie metawyborów (nie zaś na poziomie konkretnych wyborów przedmiotowych). Na metapoziomie zapadają decyzje co do stosowania lub niestosowania kryterium wyznaczającego dalej wybory przedmiotowe.

(1) Zgodnie z konwencją $T$ (konw. Tarskiego) twierdzenia zbudowane w metajęzyku i przypisujące prawdziwość twierdzeniu na gruncie języka przedmiotowego mówią to samo, co to ostatnie twierdzenie; tymczasem konwencja $G$ implikuje, że twierdzenia metajęzykowe przypisujące moc obowiązywania pewnemu twierdzeniu języka przedmiotowego wyrażają znacznie więcej aniżeli to ostatnie. Twierdzenia zbudowane w języku przedmiotowym podają jedynie zalecenia dotyczące rozstrzygnięć i decyzji, które podmiot decyzyjny może w każdej chwili zmienić lub unieważnić. Natomiast twierdzenia metajęzykowe wypowiadają się dodatkowo przeciwko takiemu unieważnieniu. To, o czym tutaj mowa jest niezmiernie doniosłe dla definicji naturalizmu praktycznego II stopnia. Gdyby wszystkie twierdzenia metajęzykowe były twierdzeniami teoretycznymi i gdyby znaczenie predykatów ważnościowych regulowane było wyłącznie przez konwencję $T$, naturalizm II stopnia dałby się sprowadzić do naturalizmu I stopnia. Stanowisko naturalizmu II stopnia daje się utrzymać jako stanowisko samodzielne tylko wówczas, gdy dopuści się metajęzykowe twierdzenia praktyczne oraz F7. Warto je utrzymać choćby dlatego, że dyskusja z nim może być nader owocna.

Zanim zagłębimy się w naturalizm praktyczny II stopnia, chciałbym jeszcze zwrócić uwagę na inną, daleko idącą konsekwencję moich badań: jeśli już raz przyjęliśmy, że wybór przedmiotowy poprzedzony jest metawyborem, to jesteśmy zmuszeni uznać 
dalej, że metawybór również poprzedzony jest możliwym meta-metawyborem czy też meta-metadecyzją. Uzyskujemy w ten sposób strukturę o podłożu otwartym:

\begin{tabular}{|l|l|l|}
\hline \multicolumn{1}{|c|}{ poziom decyzji } & \multicolumn{1}{|c|}{ alternatywy decyzji } & \multicolumn{1}{c|}{ kryteria decyzji } \\
\hline $\begin{array}{l}\text { decyzja na poziomie przedmiotowym } \\
\text { (poziomie działania) }\end{array}$ & $\begin{array}{l}\text { działanie a } \\
\text { działanie b }\end{array}$ & k: ?należy wybrać b? \\
\hline Metadecyzja & $\begin{array}{l}\text { stosowanie k } \\
\text { niestosowanie k }\end{array}$ & $\begin{array}{l}\text { gk: ?należy zastosować k podejmując } \\
\text { decyzję o działaniu? }\end{array}$ \\
\hline Meta-metadecyzja & $\begin{array}{l}\text { stosowanie gk } \\
\text { niestosowanie gk }\end{array}$ & $\begin{array}{l}\text { ggk: ?należy zastosować gk podejmując } \\
\text { metadecyzję? }\end{array}$ \\
\hline$\downarrow$ & $\downarrow$ & $\downarrow$ \\
\hline
\end{tabular}

Rys. 1.

Możliwe jest istnienie nieskończonego ciągu wyborów i decyzji poprzedzających. Oczywiście żaden podmiot decyzyjny nie będzie podejmował meta-wyborów w nieskończoność: w pewnym momencie przerwie on ten ciąg lub, mówiąc inaczej, będzie musiał gdzieś zacząć. Czy jest do tego uprawniony, zależy to od tego, jakie kryteria obowiązywania twierdzeń praktycznych stoją dla niego do dyspozycji na każdym z poziomów i czy istnieje kryterium najwyższe, którego obowiązywanie jest bezdyskusyjne. Punktem tym zajmiemy się w trzecim etapie naszych badań.

\section{Naturalizm praktyczny II stopnia? antynaturalizm praktyczny II stopnia}

Jesteśmy już teraz w stanie wyłuszczyć, co rozumiemy pod pojęciem ?naturalizmu praktycznego II stopnia?. Chodzi to o stanowisko uznające wszystkie trzy założenia antyrealizmu praktycznego, przyjmujące ponadto, że dla wszystkich predykatów o postaci: ?posiadający moc obowiązywania w języku $x$ ? istnieją tzw. zasady przechodniości (bridge-principles) uzależniające obowiązywanie twierdzenia wyrażonego w języku $x$ od tego, czy w odpowiednim twierdzeniu teoretycznym skonstatowano zachodzenie danego stanu rzeczyz. Zasady przechodniości są zdaniami syntetycznymi o takiej oto postaci:

F8: $\forall \mathrm{v}[(\mathrm{vSLp} 1$ ? Lp1 Elt1) $\rightarrow($ vGLp1 wtedy i tylko wtedy, gdy ?Tq?WLt1)]

Jak pokazuje definicja naturalizmu praktycznego II stopnia, pozostaje sprawą otwartą, czy w przypadku faktu nadającego prawdziwość twierdzeniu $T q$ chodzi o:
a. przygodny fakt empiryczny;
b. fakt empiryczny, którego konieczność wynika z jakiejś normy praktycznej;
c. fakt metafizyczny, czy może
d. fakt logiczny.

Typologiczna różnorodność faktów sprawia, że istnieją rozmaite typy etyki naturalistycznej:
a. etyka o przygodnych podstawach empirycznych;
b. etyka oparta na zasadach empirycznych;
c. etyka metafizyczna;
d. etyka logiczna.

Jako przykład etyki metafizycznej podać można stoicyzm lub neoplatonizm; przykładem etyki logicznej jest praktyczna teoria koherencji zakładająca, że twierdzenie praktyczne obowiązuje wtedy i tylko wtedy, gdy jest elementem jakiegoś spójnego systemu twierdzeń uznanych za obowiązujące. Wszelako, na miano ?naturalizmu praktycznego? w ścisłym sensie zasługuje wyłącznie stanowisko, które dopuszcza, by moc obowiązywania twierdzeń praktycznych była zależna od faktów empirycznych, a dokładniej: od przygodnych faktów empirycznych. Jak zapowiadałem na początku, w trzeciej części moich badań podejmę tę właśnie postać naturalizmu praktycznego II stopnia.

Porównanie $F_{3}$ i $F 8$ unaocznia, że naturalizm praktyczny II stopnia nie jest tożsamy z realizmem praktycznym. To, co w F3 znajduje się po prawej stronie oznaczenia ?wtw? nie jest bowiem faktem praktycznym, lecz faktem teoretycznym. 
Wychodząc od $F 8$, możemy również wykazać, dlaczego podana przez nas definicja semantyczna predykatu ?v posiada moc obowiązywania w języku $x$ ? leżeć musi u podstaw formuły naturalizmu praktycznego II stopnia. Gdybyśmy w twierdzeniu $F 8$ zastąpili wyrażenie $G$ [= praktyczna moc obowiązywania] wyrażeniem $W$ [= teoretyczna moc obowiązywania, czyli prawda], co należałoby uczynić, gdyby nie istniało pojęcie praktycznego obowiązywania, to dla każdego twierdzenia $S T p \mathrm{w}$ języku Lp1 można by zbudować formułę typu $F_{9}$ :

F9: ?STp? jest prawdziwe wtedy i tylko wtedy, gdy Tq

Po uproszczeniu otrzymujemy twierdzenie F1O:

F10: STp wtedy i tylko wtedy, gdy Tq

Łatwo dostrzec, że F1o jest formułą adekwatną dla naturalizmu I stopnia. Naturalizm praktyczny II stopnia twierdzi wobec tego, że (zgodnie z zasadą przechodniości) moc obowiązywania wszystkich twierdzeń praktycznych we wszystkich językach zależy od prawdziwości twierdzenia teoretycznego, sformułowanego w tym języku teoretycznym, którego rozszerzeniem jest język praktyczny. Stanowisko to wyrazić możemy poprzez koniunkcję czterech twierdzeń:

(ANIb) $\forall \mathrm{x} \forall \mathrm{y} \forall \mathrm{v} \forall \mathrm{v}$ ? [(vSx ? $\mathrm{xEy}$ ? v?Sy) $\rightarrow \sim \mathrm{vBv}$ ?]

(O) $\exists x \exists u[u S x ? u D x]$

(AR) $\exists \mathrm{x} \exists \mathrm{v}[\mathrm{vSx} ? \mathrm{vDx} ? \sim \mathrm{vFx} ? \sim \mathrm{vWx}]$

(NIIa) $\forall x \forall y \forall v \forall v$ ? [(vSx ? xEy ? vGx) $\rightarrow(v$ ? Sy ? v?Wy ? (v?Wy $\leftrightarrow v G x))]$

Od radykalnego naturalizmu praktycznego II stopnia należy odróżniać umiarkowany naturalizm praktyczny II stopnia, który w miejsce NIIa przyjmuje NIIb.

(NIIb) $\exists x \exists y \exists y \exists v$ ? [vSx ? vEy ? vGx ? v?Sy ? v?Wy ? (v?Wy $\leftrightarrow$ vGx)]

Przeciwnicy naturalizmu praktycznego II stopnia nie zaprzeczą jednak, że istnieją zasady przechodniości, zgodnie z którymi moc obowiązywania twierdzeń praktycznych zależy od uprzednio zaistniałych faktów teoretycznych. Odrzucą oni jedynie to, że zasady takie zachowują bezwyjątkową ważność dla wszystkich twierdzeń praktycznych. Możemy zatem scharakteryzować antynaturalizm praktyczny II stopnia za pomocą koniunkcji następujących twierdzeń:

(ANIb) $\forall \mathrm{x} \forall \mathrm{y} \forall \mathrm{v} \forall \mathrm{v}$ ? [(vSx ? $\mathrm{xEy}$ ? v?Sy) $\rightarrow \sim \mathrm{vBv}$ ?]

(O) $\exists \mathrm{x} \exists \mathrm{v}[\mathrm{vSx} ? \mathrm{uD}]$

(AR) $\exists \mathrm{x} \exists \mathrm{v}[\mathrm{vSx} ? \mathrm{vDx} ? \sim \mathrm{vFx} ? \sim \mathrm{vWx}]$

(ANII) $\exists \mathrm{x} \exists \mathrm{y} \exists \mathrm{v} \exists \mathrm{v}$ ? [(vSx ? xEy ? vGx ? v?Sy ? v?Wy) $\sim(\mathrm{v}$ ?Wy ? vGx)]

Stanowisko to harmonizuje z umiarkowanym naturalizmem praktycznym II stopnia.

\section{$*$}

3) Okazuje się, że radykalny naturalizm praktyczny II stopnia (wedle uzyskanej wyżej definicji) jest znacznie mniej kłopotliwy niż podejrzewają zagorzali antynaturaliści. Większość tradycyjnych systemów filozofii praktycznej uznaje bowiem implicite lub explicite to, że obowiązywanie twierdzeń praktycznych zależy od określonych faktów. I tak np. obowiązywanie Kantowskiego imperatywu kategorycznego zależy od istnienia skończonych istot rozumnych. Imperatyw ten uzależnia nawet obowiązywanie zasad praktycznych od logicznej właściwości (faktu), iż zasady te dają się uniwersalizować. Można więc powątpiewać, czy istnieje jakakolwiek filozofia praktyczna wolna od tego rodzaju zależności.

Aby przenieść całą dyskusję na bardziej żyzny grunt, chciałbym zająć się dalej takimi wersjami naturalizmu praktycznego II stopnia, które dopuszczają, aby obowiązywanie twierdzeń praktycznych zależało od tego, że zaszły uprzednio pewne przygodne fakty empiryczne. Wersje te odpowiadają pierwotnej definicji wyrażenia ?naturalistyczny?, podanej przez G.E. Moore?a. Stanowisko to nazwiemy ?praktycznym naturalizmem $E K$ ? (= o kontyngentnych resp. przygodnych podstawach empirycznych). Szczególnie frapującą postać takiego naturalizmu stanowią teorie, wedle których obowiązywanie twierdzeń praktycznych zależy jest od przygodnych własności empirycznych tych samych twierdzeń, tzn. od faktów, których nazwanie wymaga tychże twierdzeń.

Na początek wskażę tylko ogólnie na trudności, jakie pociągają za sobą tego rodzaju stanowiska, jeśli przybierają postać radykalną. Następnie przywołam dwie specyficzne formy naturalizmu radykalnego II stopnia, a

mianowicie: konwencjonalizm i pragmatyzm, wedle których zachodzenie stanów rzeczy przesądzających o obowiązywaniu twierdzeń praktycznych to nie tylko kwestia przygodności, lecz także decyzji ze strony ludzkich podmiotów. 
Najpierw jednak postawić musimy pytanie o status zasad przechodniości, jakich przyjęcia wymaga naturalizm praktyczny typu EK. Są one z pewnością twierdzeniami należącymi do najbliższego możliwego metajęzyka. Pozwalają one za pomocą podanego niżej sylogizmu rozstrzygać o obowiązywaniu lub nieobowiązywaniu wszelkich twierdzeń praktycznych należących do języka niższego stopnia. Jeśli będzie to twierdzenie $S T p$ należące do języka $L p 1$, o własności empirycznej $Q$, dla którego ważność posiada zasada przechodniości

B1: $\forall \mathrm{v}[(\mathrm{vSLp} 1 ? \mathrm{Qv}) \leftrightarrow \mathrm{vGLp}]$

?, to sylogizm będzie wyglądał następująco:

PI: $\forall \mathrm{v}[(\mathrm{vSLp} 1$ ? Qv) $\leftrightarrow \mathrm{vGLp} 1]$

PII: ?STp? jest twierdzeniem języka Lp1 i ?STp? posiada własność Q

C1: ?STp? posiada moc obowiązującą na gruncie języka LP1

PI, PII i CI są twierdzeniami metajęzyka Lp2, utworzonego przez rozszerzenie $L p 1$.

Pytanie jest obecnie takie: czy PI jest twierdzeniem praktycznym, czy teoretycznym, i czy metajęzyk jest językiem praktycznym, czy teoretycznym?. Odpowiadam, że PI i C1 są twierdzeniami praktycznymi, wskutek czego język, w którym zostały sformułowane, jest językiem praktycznym. Przemawiają za tym następujące argumenty:

1) Zgodnie z definicją podaną na wstępie twierdzenie jest twierdzeniem praktycznym wtedy i tylko wtedy, gdy zawiera ono terminy praktyczne, a ściślej: terminy te nie mogą być tylko przywołane, lecz muszą być rzeczywiście użyte. Jak widać, zachodzi to właśnie w przypadku $P_{1}$ i $C 1$.

2) Obok argumentu czysto syntaktycznego istnieje także argument semantyczny. $C 1$ pełni bowiem funkcję kryterium rozstrzygającego dla podmiotu decyzyjnego, który musi się zdecydować na zastosowanie lub niezastosowanie STp. Stąd też $C 1$ jest twierdzeniem praktycznym. Ponieważ sylogizm mający w konkluzji (conclusio) prawidłowo wyprowadzone twierdzenie praktyczne musi mieć wśród przesłanek co najmniej jedno twierdzenie praktycznęㅛ, to co najmniej jedno z twierdzeń (PI lub PII) jest twierdzeniem praktycznym. Jeśli nie oba twierdzenia (co jest rzecz jasna możliwe), to przynajmniej PI musi być uznane za zasadę przechodniości.

Analogicznie dla wszystkich zasad przechodniości wysuwanych przez naturalizm praktyczny typu EKwykazać się daje, że chodzi o twierdzenia praktyczne, a ponadto, że języki, w których zostały one zbudowane, także są językami praktycznymi.

Kolejna kwestia to moc obowiązywania zasad przechodniości. Podmiot decyzyjny może bowiem w każdej chwili spytać: powinien czy nie powinien stosować daną zasadę przechodniości? Problem ten daje się rozstrzygnąć tylko wówczas, gdy istnieje kryterium pozwalające odróżnić obowiązujące zasady przechodniości od tych, które nie obowiązują. W tym miejscu naturalizm praktyczny typu $E K$, że kryterium takie istnieje zawsze, i że ma ono postać zasady przechodniości. Zasada ta uzależnia obowiązywanie twierdzeń praktycznych metajęzyka pierwszego stopnia od pewnej empirycznie stwierdzalnej, przygodnej własności tych twierdzeń.

Weźmy przykładowo nasze twierdzenie PI, sformułowane w języku Lp3:

C2: PI jest ważne w języku Lp2

Aby wyprowadzić twierdzenie $C 2$, potrzeba zasady przechodniości sformułowanej w metajęzyku Lp3. Przyjmujmy, że chodzi tu o następujące twierdzenie:

B2: $\forall \mathrm{v}[(\mathrm{vSLp} 2$ ? Q3v) $\leftrightarrow \mathrm{vGLp} 2]$

Q3 stanowi izomorficzny przekład Q1 na metajęzyk Lp3. Nie ma jednak potrzeby, aby zasady przechodniości wskazywały we wszystkich metajęzykach zawsze te same własności będące kryteriami obowiązywania. Istnieje bowiem i taka możliwość, że własność ta będzie na poziomie każdego metajęzyka zupełnie inna. W moim wywodzie różnica ta nie odgrywa wszak żadnej roli. Ważniejsze jest to, że $B 2$ także jest twierdzeniem praktycznym, w odniesieniu do którego możemy pytać, czy powinno się je stosować? Aby odpowiedzieć na to pytanie, naturalista praktyczny musi sformułować zasadę przechodniości w najbliższym możliwym metajęzyku. Zasada ta wskaże empirycznie sprawdzalną, przygodną właściwość typu $E K$, która ? przysługując twierdzeniom praktycznym zbudowanym w języku $L p 3$ ? stanowi kryterium obowiązywania tych twierdzeń. Łatwo dostrzec, że takie samo zadanie czeka nas na każdym kolejnym metapoziomie językowym. Wypływa stąd postulat nieskończonego szeregu jednorodnych lub niejednorodnych zasad przechodniości. A ponieważ regresu nie da się zamknąć, obowiązywanie twierdzenia praktycznego nie będzie ostateczne na żadnym z poziomów.

Dotyczy to także przypadku dotąd nie omówionego, polegającego na tym, że przygodny fakt empiryczny, od którego zależy obowiązywanie twierdzenia praktycznego (inaczej aniżeli w podanym wyżej przykładzie) nie odnosi się do tego twierdzenia. Weźmy tak oto sformułowaną zasadę przechodniości: 
B1: $\forall \mathrm{v}[(\mathrm{vSLp} ? \mathrm{Tp}) \leftrightarrow \mathrm{vGLp} 1]$

$B 1$ jest najwyraźniej twierdzeniem praktycznym, należącym do metajęzyka Lp2. Zgodnie ze stanowiskiem naturalizmu praktycznego typu $E K$ obowiązywanie $B 1$ zależy od zasady przechodniości $B I I$ zbudowanej w języku Lp2 oraz faktu, który (według tejże zasady) implikuje obowiązywanie twierdzeń języka Lp2. Ponieważ BII znów jest twierdzeniem praktycznym zbudowanym w najbliższym możliwym metajęzyku, także i tu popaść musimy w nieskończony regres.

Moglibyśmy próbować uchronić się przez regresem, tworząc zasadę przechodniości Ba wskazującą pewien przygodny warunek empiryczny, pod którym obowiązują twierdzenia wszystkich języków praktycznych, i która to zasada wyróżniałaby $B 2$ jako twierdzenie należące do jednego z nich, tj. do najwyższego możliwego metajęzyka. Metajęzyk ten pozwalałby wypowiadać się także o jego własnych twierdzeniach.

Ba: $\forall v \forall x[(v S x ? T p) \leftrightarrow v G x]$

Przyjmując to założenie, popadniemy jednak nieuchronnie w sytuację przypominającą paradoks kłamcy. Jeśli bowiem $T p$ jest fałszywe (czego nie sposób wykluczyć, skoro Tp jest przygodnym faktem empirycznym), to twierdzenie $B a$ nie posiada ważności. A jeśli $B a$ nie posiada ważności, to niewykluczone, że $B a$ obowiązuje mimo to, ponieważ jego obowiązywanie nie zależy już od $T p$. Ba obowiązuje, lecz zarazem obowiązywać nie może, ponieważ Tp jest fałszywe.

Przeciwko $B a$ przemawia też to, że możemy sformułować dowolne zasady przechodniości, które wszystkie co do jednej zawierać będą podstawę własnej prawomocności. Owa dowolność sprawia, że zasady te okażą się bezużyteczne, gdy zechcemy posłużyć się nimi do uprawomocnienia twierdzeń praktycznych: innymi słowy, pozwolą one uprawomocnić dowolne twierdzenie praktyczne.

Tego typu paradoksów i nieskończonych regresów uniknąć możemy tylko w ten sposób, że przyjmiemy, iż na pewnym nieskończonym poziomie językowym mogą istnieć ważne twierdzenia praktyczne, których moc obowiązywania nie zależy od przygodnych faktów empirycznych. W moim przekonaniu naturalizm praktyczny stopnia II $b$ stanowi jedyną akceptowalną postać praktycznego naturalizmu typu EK. Tezę tę chciałbym dodatkowo podeprzeć analizą i jednocześnie krytyką dwóch najważniejszych teorii naturalistycznych, czyli konwencjonalizmu i pragmatyzmu. Krytyka ta obejmie również ich głębokie wzajemne powiązania.

Jak wiadomo, istnieje mnóstwo najrozmaitszych odmian konwencjonalizmu. Ograniczę się tutaj do wyróżnienia odmiany szczególnie prostej. Wszystkie odmiany konwencjonalizmu mają jedną wspólną cechę: uzależniają one obowiązywanie twierdzeń praktycznych od faktu, jakim jest określona konwencja. Różnią się z uwagi na to, co takiego uznane jest za konwencję. Najmniej problematyczny jest przypadek, gdy konwencją jest explicite wyrażone samozobowiązanie podmiotu decyzyjnego lub grupy takich podmiotów do stosowania danego twierdzenia praktycznego we wszystkich podpadających pod nie sytuacjach decyzyjnych. Okazuje się przy tym, że konwencjonalizm taki nakłada na predykat ?obowiązujący? dwojakiego rodzaju ograniczenie. Musi on być ograniczony nie tylko do określonego języka praktycznego, lecz także do określonej grupy społecznej. Nie jest to jednak coś, co przemawiałoby przeciwko konwencjonalizmowi: w rzeczywistości bowiem większość ważnych twierdzeń praktycznych jest zrelatywizowana. Posiadają one moc obowiązywania tylko dla określonej grupy społecznej.

Dla konkretnego języka praktycznego Lp1 wskazać można taką oto konwencjonalistyczną zasadę przechodniości:

BLp1: ?Dla wszystkich twierdzeń praktycznych v w języku Lp1 i dla wszystkich podmiotów s, władających tym językiem jest tak, że: v posiada moc obowiązującą w Lp1 dla podmiotu s wtedy i tylko wtedy, gdy s zobowiązał się w najbliższym metajęzyku Lp2 do stosowania v we wszystkich sytuacjach podpadających pod v?.

$\forall \mathrm{v} \forall \mathrm{s}[\mathrm{vGLp} 1 \mathrm{~s} \leftrightarrow(\mathrm{vSLp} 1$ ? sSPRLp1 ? sSPRLp2 ? vVLp2s)]

Binarna relacja $v V L p 2 s$ ma jednak miejsce wtedy i tylko wtedy, gdy zachodzi co najmniej jedno wydarzenie $r$, opisane następująco: $s$ dokonuje (kontraktualistycznego) aktu samozobowiązania, że będzie przestrzegać zasady praktycznej $v$. Zasadę przechodniości możemy sformułować tak oto:

BLp1: ?Dla wszystkich twierdzeń praktycznych v języka praktycznego Lp1 i dla wszystkich podmiotów s jest tak, że: v obowiązuje w Lp1 dla s wtedy i tylko wtedy, gdy zachodzi co najmniej jedno wydarzenie r, takie, że r jest aktem zobowiązania się przez s do v w metajęzyku Lp2?.

$\forall \mathrm{v} \forall \mathrm{s}[\mathrm{vGLp} 1 \mathrm{~s} \leftrightarrow \exists \mathrm{r}(\mathrm{rAVsv})]$

Ponieważ BLp1 jest twierdzeniem należącym do metajęzyka w stosunku do $L p 1$ i $L p 2$, potrzebujemy zasady przechodniości wyższego rzędu, aby móc rozstrzygnąć, czy BLp1 posiada moc obowiązującą. Zasada ta może (choć nie musi) być zasadą konwencjonalistyczną, tj. jednorodnym (homomorficznym) przekładem BLp1 na odpowiedni, wyższy metajęzyk. Tak czy inaczej, z powodów stricte formalnych dochodzi tutaj do nieskończonego regresu. Jeśli nam to nie przeszkadza, możemy sformułować ogólną, konwencjonalistyczną zasadę przechodniości: 
UKB1: ?Dla wszystkich twierdzeń praktycznych v w języku praktycznym x i dla wszystkich s używających x jest tak, że v posiada moc obowiązywania w języku x dla s wtedy i tylko wtedy, gdy istnieje metajęzyk z nadrzędny w stosunku do x, tak, że s jest użytkownikiem z oraz s zobowiązało się (na sposób kontraktualistyczny) do stosowania v we wszystkich sytuacjach podpadających pod v?.

$\forall \mathrm{x} \forall \mathrm{v} \forall \mathrm{s}[\mathrm{vGxs} \leftrightarrow \exists \mathrm{z}(\mathrm{zMx}$ ? sSPRz ? vVzs)]

Konwencjonalista wyznający UKB1 dysponuje dwiema strategiami pozwalającymi mu uprawomocnić obowiązywanie UKB1: może on próbować wykazać obowiązywanie UKB1 za pomocą różnej od UKB1zasady przechodniości lub też wykorzystać $U K B 1$ do uprawomocnienia tego samego $U K B 1$ (byłoby to wówczas samouprawomocnienie). Wszelako: w pierwszym przypadku konwencjonalista musi rozstać się z zasadą $U K B 1$. Jeśli bowiem moc obowiązywania $U K B$ zależna jest od czegoś innego aniżeli od kryteriów sformułowanych w $U K B 1$, to kryteria te tracą ważność i zastosowanie dla wszelkich twierdzeń praktycznych we wszystkich językach praktycznych. Pozostaje mu więc samouprawomocnienie zasady UKB1 przez tę samą zasadę. Przeciwko temu podnieść można najpierw zarzuty formalne: strategia ta prowadzi bowiem do circulus in demonstrando. Niemniej zachodzi tu podejrzenie, że jest to circulus vitiosus. Jeśli nawet zgodzimy się, że dla konwencjonalisty jest to błąd niewinny, nie rozwiązuje to jeszcze całego problemu. Aby uprawomocnić obowiązywanie UKB1, musi on powołać się na zdarzenie, które opisuje następująca formuła: co najmniej jeden podmiot praktyczny zobowiązuje się w metajęzyku nadrzędnym wobec tego, w którym sformułowane jest $U K B 1$ do stosowania $U K B 1$ we wszystkich podpadających pod UKB1 sytuacjach. Jako pierwszy pojawia się tutaj problem, czy może istnieć metajęzyk nadrzędny wobec UKB1? Nazwijmy język, w którym sformułowano UKB1, językiem Ma. Wyróżnijmy go jako metajęzyk w stosunku do wszystkich języków, tzn. jako język powiadający o tych wszystkich językach, które nie powiadają same o sobie. Czytelnik obeznany z historią logiki i semantyki zauważy tu od razu, że proponując taką formułę, uwikłaliśmy się w paradoks podobny do paradoksu Russella. Musimy więc wybrać dla $M a$ inną charakterystykę. Ponieważ UKB1 powiada coś o wszystkich językach praktycznych, $M a$ musi być językiem, który pozwala formułować wypowiedzi zarówno w odniesieniu do samego siebie, jak i w odniesieniu do wszystkich innych języków praktycznych. Zabieg taki ściągnąłby najpierw na Ma te same kłopoty, których chcieliśmy uniknąć postulując, aby o danym języku można było mówić wyłącznie w metajęzyku (nigdy zaś w tym samym języku). Jednak mimo, że niektórzy - święcie przekonani o tym, że problemy te dadzą się przezwyciężyć, jeśli tylko zachowana zostanie należyta ostrożność ? akceptują tę propozycję (koncepcji takiego metajęzyka bronił Quine, 1991), nie jest to jeszcze koniec tunelu. Najpierw bowiem trzeba zmodyfikować UKB1. Na miejscu formuły ?wtedy i tylko wtedy, gdy istnieje język z, nadrzędny wobec x? umieścić należy formulę: ?wtedy i tylko wtedy, gdy x pozwala wypowiadać się o samym sobie albo gdy istnieje metajęzyk z, nadrzędny wobec języka $x$, i gdy s jest użytkownikiem języków x i z, który zobowiązał się w języku x lub z do stosowania $v$ we wszystkich sytuacjach podpadających pod $v$ ?. Oto zmodyfikowane twierdzenie UKB2:

$\forall \mathrm{x} \forall \mathrm{v} \forall \mathrm{s}\{\mathrm{vGxs} \leftrightarrow([\mathrm{xMx}$ ? sSPRx ? vVxs] *or; $\exists \mathrm{z}[\mathrm{zMx}$ ? sSPRz ? vVzs $])\}$

Przyjmijmy, że konwencjonaliści wyznają UKB2. Jest wobec tego tak, że UKB2 nie ma mocy obowiązywania dopóty, dopóki pewna grupa podmiotów nie zobowiąże się w języku $M a$ do stosowania UKB2. Pytanie jest takie: czy możliwe jest uprawomocnienie UKB2 poprzez taki właśnie akt? Akt ten jest bowiem w stanie nadać moc obowiązywania UKB2 wtedy i tylko wtedy, gdy UKB2taką już moc posiada: ponieważ jednak UKB2 nie posiada mocy obowiązywania przed tym aktem, to akt także sam nie ma żadnej mocy nadania mocy obowiązywania twierdzeniu UKB2.

Końcowy wniosek, jaki wypływa z naszych analiz, byłby taki, że radykalny konwencjonalizm głoszący UKB2 musi zrezygnować z uprawomocnienia zarówno $U K B 2$, jak i wszelkich innych twierdzeń praktycznych. Konwencjonalizm ten nie może więc głosić UKB2 i musi zastąpić to twierdzenie zasadą słabszą od niego. Może nią być następujące twierdzenie

$\mathrm{UKB}_{3}: \forall \mathrm{x} \forall \mathrm{v} \forall \mathrm{s}\{([\mathrm{xMx}$ ? sSPRx ? vVxs] $\vee \exists \mathrm{z}[\mathrm{zMx}$ ? sSPRz ? vVzs] $) \rightarrow \mathrm{vGxs}\}$

W porównaniu z UKB2 twierdzenie $U K B 3$ posiada tę zaletę, że jego moc obowiązywania nie zakłada jako swego warunku, aby podmiot nadawał mu moc przez dokonanie samozobowiązania. Skoro więc posiada ono bezwarunkową moc praktyczną, to może też stanowić najwyższe konwencjonalistyczne kryterium obowiązywania wszystkich pozostałych twierdzeń praktycznych. Umiarkowani konwencjonaliści, będąc zwolennikami praktycznego naturalizmu $E K$ (opartego na empirii i przygodności) typu II b będą więc głosili UKB3 przyjmując, że zasada ta jest bezwarunkowo obowiązującym twierdzeniem praktycznym, które, jeśli w ogóle daje się uprawomocnić, to tylko za pomocą argumentów transcendentalnych.

Nie jest to jednak jedyna opcja, jaką dysponują praktyczni naturaliści $E K$. Mogą oni próbować ratować radykalny naturalizm $E K$, próbując uprawomocnić $U K B 3$ inną naturalistyczną zasadą przechodniości, tak, że moc obowiązywania wszystkich twierdzeń praktycznych zależeć będzie wówczas od jakiegoś przygodnego faktu empirycznego (jak zakłada to praktyczny naturalizm EK typu II a). Chciałbym tę opcję zbadać i poddać krytyce, posługując się konkretną propozycją.

Argumentacja pragmatyczna otwiera najszersze perspektywy i jest najczęściej obieraną drogą do uprawomocnienia konwencjonalizmu na gruncie naturalistycznym. Wszystkie argumenty pragmatyczne opierają się na zasadzie imperatywów hipotetycznych. Zasadę tę formułuje się często w odwołaniu do Kanta (por. Seel, 1989, ss. 148-171, a także Kant, Uzasadnienie metafizyki moralności, 417, gdzie powiada się, że ten, kto pragnie celu, pragnie też ? w zgodzie z rozumem ? tych właśnie środków, które zawiodą go niezawodnie do tego celu). W wersji formalnej zasada ta wygląda tak: 
PHI: $\forall \mathrm{s} \forall \mathrm{m} \forall \mathrm{n}[(\mathrm{mMIn} ? \mathrm{sWTn}) \rightarrow$ STsWTm $]$

Posługując się tą zasadą w sposób typowy dla utylitaryzmu reguł, można uprawomocnić UKB3. Przyjmijmy, że kontrahenci ?umowy?, zobowiązujący się do przestrzegania twierdzenia praktycznego, dążą przy tym do osiągnięcia własnych, subiektywnych celów, i że cele te zostaną osiągnięte tylko wtedy, gdy większość kontrahentów rzeczywiście przestrzegać będzie wspólnie uzgodnionej zasady praktycznej. Przyjmijmy dalej, że jeśli któryś z kontrahentów nie będzie tej zasady przestrzegał, to gotowość jej do przestrzegania ze strony pozostałych drastycznie spadnie. Okazuje się, że dla każdego z kontrahentów jego własne, konsekwentne przestrzeganie zasady stanowi środek konieczny do osiągnięcia (subiektywnego) celu. Zgodnie z PHI, powinien on zatem chcieć przestrzegać owej zasady praktycznej. Oznacza to, że w każdej sytuacji, kiedy trzeba zdecydować o tym, czy zasady tej przestrzegać, czy nie przestrzegać, powinien on wybrać pierwszy wariant. UKB3 głosi to w stosunku do wszystkich twierdzeń, będących przedmiotem samozobowiązania ze strony podmiotu. W ten sposób UKB3 zostaje pragmatyczne uprawomocnione.

Nie chciałbym wdawać się w dyskusje o tym, jak realistyczne są założenia poczynione w argumencie pragmatycznym: zamiast tego rozsądniej będzie skoncentrować się na statusie PHI. Otóż dla pragmatyzmu PHI stanowi fundamentalną zasadę przechodniościq. Łatwo przy tym dostrzec, że chodzi tu o naturalistyczną zasadę przechodniości, która pozwala wyprowadzić twierdzenie praktyczne z twierdzeń teoretycznych, mających charakter empiryczny i przygodny. Wszelako, jest to naturalizm I stopnia. PHI nie uzależnia tu mocy obowiązywania danego twierdzenia praktycznego o jakiegoś przygodnego faktu empirycznego, lecz uzależnia odeń tylko to, co powiedziano w tym twierdzeniu. Jest to okazja do tego, by na nowo rozważyć stosunek między naturalizmem praktycznym I stopnia i naturalizmem praktycznym II stopnia. Mianowicie nadal utrzymujemy, że naturalizm praktyczny II stopnia nie może być zredukowany do naturalizmu praktycznego I stopnia. Jednak pewne odmiany naturalizmu praktycznego II stopnia ? np. konwencjonalizm ? dają się uprawomocnić za pomocą pewnych odmian naturalizmu praktycznego I stopnia, np. pragmatyzmu. Zakłada to, że PHI jest twierdzeniem o mocy obowiązywania, co też wymaga dowodu. Większość filozofów uważa, że jest z takiego dowodu zwolniona, ponieważ ? podobnie jak Kant ? żywią oni przekonanie, że $P H I$ jest twierdzeniem analitycznie prawdziwym.

Toczone w minionych latach dyskusje (por. Seel, 1989, ss. 160?167 i podaną tam literaturę) pokazały jednak, że tezie o tym, jakoby zasada imperatywu hipotetycznego była twierdzeniem analitycznie prawdziwym, można wiele zarzucić. Skoro jednak wysiłki uprawomocnienia praktycznego obowiązywania PHI (przez wykazanie, że chodzi o twierdzenie analityczne) spełzają dotąd na niczym, to wypadnie je uprawomocnić w inny sposób. Zwolennicy radykalnego naturalizmu typu EK mają tylko jedno wyjście: muszą oni podać naturalistyczną zasadę przechodniości, a następnie wykazać, że $P H I$ spełnia kryterium empirycznej przygodności, wyznaczone przez tę zasadę. Jeśli chcemy pozostać w dziedzinie wskazanych dotychczas zasad przechodniości, to widzę tutaj dwie możliwe drogi: (a) próbę samouprawomocnienia twierdzenia PHI; (b) uprawomocnienie PHI w sposób konwencjonalistyczny.

Ad. (a): Można by wysunąć argument, że podmiot dążący do dowolnego celu osiągnie ten cel z prawdopodobieństwem wyższym niż 0,5 wtedy, gdy będzie przestrzegał PHI. Przestrzeganie $P H I$ jest więc samo przez się środkiem koniecznym do tego, by w sposób względnie pewny osiągnąć obrany cel. Zatem podmiot chcący w sposób względnie pewny osiągnąc własne cele powinien przestrzegać $P H I$. W rezultacie $P H I$ obowiązuje praktycznie grupę takich podmiotów, które - z pewnością wyższą od średniej ? pragną osiągnąc swoje cele.

Argument ten wprowadza pojęcie meta-celu, tzn. takiego celu, którym jest osiągnięcie wszystkich pozostałych celów z pewnością wyższą od średniej. Niewątpliwie taki meta-cel daje się nie tylko pomyśleć, lecz może być przedmiotem dążeń dla wielu podmiotów. Nie ulega też wątpliwości, że środkiem niezbędnym do osiągnięcia meta-celu jest przestrzeganie PHI. Od tej strony naszej argumentacji nie można niczego zarzucić. Jednak argument mający uprawomocnić $P H I$ zakłada, że $P H I$ już pierwotnie posiada moc obowiązywania praktycznego. Jednak dopóki obowiązywanie PHInie zostało uprawomocnione, niedopuszczalne jest stosowanie PHI w jakiejkolwiek argumentacji (byłoby to bowiem reductio ad absurdum). Zarysowany tutaj ciąg argumentacyjny należy odrzucić, ponieważ prowadzi do błędnego koła.

Ad. (b): Można obrać argumentację alternatywną, że $P H I$ obowiązuje praktycznie tych, którzy (wspólnie lub indywidualnie) zobowiązali się do stosowania $P H I$ we wszystkich przypadkach podpadających pod $P H I$. Motywem samozobowiązania może być świadomość roli, jaką PHI odgrywa przy osiąganiu dowolnych celów. Jednak także i ta argumentacja nie nadaje się do przyjęcia. Zakłada ona bowiem, że obowiązuje konwencjonalistyczna zasada przechodniości, które nie udało nam się dotąd uprawomocnić w sposób akceptowalny logicznie. Samouprawomocnienie jest bowiem problematyczne z punktu widzenia logiki, zaś uprawomocnienie pragmatyczne jest nie do przyjęcia, dopóki pod znakiem zapytania stoi obowiązywanie $P H I$.

Próby uprawomocnienia konwencjonalizmu na drodze pragmatycznej (tj. UKB3 przez $P H I$ ) a pragmatyzmu na drodze konwencjonalistycznej (tj. PHI przez UKB3) prowadzą do dwoistości (Diallele). Dwoistości dają się utrzymać tylko na gruncie teorii koherencji (Brink, 1989, s. 122). Podnoszony zwykle zarzut przeciwko teorii koherencji głosi, że zbiór twierdzeń może być spójny mimo zawartego w niej podzbioru twierdzeń fałszywych, nie został dotąd obalony i wystarcza do tego, by uznać teorię koherencji ? także w jej wersji epistemologicznej ? za stanowisko nie do przyjęciaıo W tej sytuacji zwolennikom radykalnego naturalizmu praktycznego typu EK pozostaje tylko jedna możliwość: wyprowadzić nową naturalistyczną zasadę przechodniości i 
uprawomocnić dzięki niej UKB3 lub PHI. Zabieg ten będzie mógł się jednak powieść tylko wtedy, gdy zasada sama będzie mieć moc obowiązującą.

Naturalistyczne zasady przechodniości mogą mieć charakter radykalny lub umiarkowany. Zasady radykalne mówią, że twierdzenia praktyczne posiadają moc obowiązującą tylko wtedy, gdy zachodzą pewne przygodne fakty empiryczne: zasady te napotykają na trudności logiczne wspomniane na początku tego paragrafu. Zasady umiarkowane powiadają jednostronnie, że pewne przygodne fakty empiryczne implikują obowiązywanie stosownych twierdzeń praktycznych: unikają one wspomnianych trudności. Jednakże na gruncie naturalizmu praktycznego typu EK II a obowiązywanie umiarkowanych zasad przechodniości ? jak pokazaliśmy wyżej - daje się uprawomocnić tylko za pomocą innych naturalistycznych zasad przechodniości. Grozi to popadnięciem albo w nieskończony regres, albo w błędne koło, albo przyjęciem zasady radykalnego naturalizmu, co jest nie do utrzymania z przyczyn immanentnie logicznych.

Konkluzje płynące z tych badań są takie, że zwolennicy naturalizmu praktycznego typu EK II stopnia zmuszeni są przyjąć naturalistyczne ograniczenie dla co najmniej jednej z proponowanych przez nich zasad przechodniości. Muszą przyjąć, że praktyczne obowiązywanie przynajmniej jednej z tych zasad nie zależy od przygodnych faktów empirycznych. Według mnie tu właśnie leży nieprzekraczalna granica praktycznego naturalizmu typu EK. Jest on do przyjęcia tylko w postaci naturalizmu praktycznego typu EK II b. W swej umiarkowanej wersji naturalizm praktyczny nie kłóci się z filozofią transcendentalną. Zakłada bowiem konieczność przyjęcia najwyższych zasad praktycznych, których obowiązywanie jest warunkiem prawomocności innych zasad praktycznych. Same te zasady nie dają się jednak uprawomocnić w sposób naturalistyczny.

Można się oczywiście nadal spierać o to, jakiej zasadzie lub jakim zasadom przysługuje taki status. Zaproponowałem kiedyś (Seel, 1983, ss. 609?619) procedurę mającą pomóc odsłonić najwyższą zasadę praktyczną i sformułowałem też twierdzenie, które przy zastosowaniu tej procedury kandydować może do miana najwyższego pryncypium praktycznego. Celem niniejszego artykułu nie było jednak ustanawianie nonnaturalistycznych pryncypiów praktycznych. Chodziło mi jedynie o pokazanie, że również naturaliści dostarczyć muszą takich pryncypiów, jeśli nie chcą rezygnować z moralnego osądu ludzkich działań, z waloryzacji, nagradzania i karania, albo ? krótko mówiąc ? z sądów o praktycznych roszczeniach ważnościowych.

\begin{tabular}{ll}
$\sim$ & negacja \\
$?$ & implikuje w sposób praktyczny \\
$?$ & implikacja materialna \\
V & koniunkcja \\
p, q & dysjunkcja \\
Lp & jtałe oznaczające stan rzeczy \\
Lt & język teoretyczny \\
Lp1, Lp2 & stałe oznaczające języki praktyczne \\
Tp & jest tak, że (operator twierdzenia teoretycznego) \\
S & zmienna oznaczająca podmioty (Subject) \\
x & zmienna oznaczająca język praktyczny \\
y & zm. oznaczająca język teoretyczny \\
z & zm. oznaczająca języki praktyczne i teoretyczny \\
v, v?, u & zmienne oznaczające twierdzenia \\
m, n & zmienne oznaczające stany rzeczy \\
vSx & v jest twierdzeniem języka x \\
xEy & x jest rozszerzeniem y \\
\hline
\end{tabular}




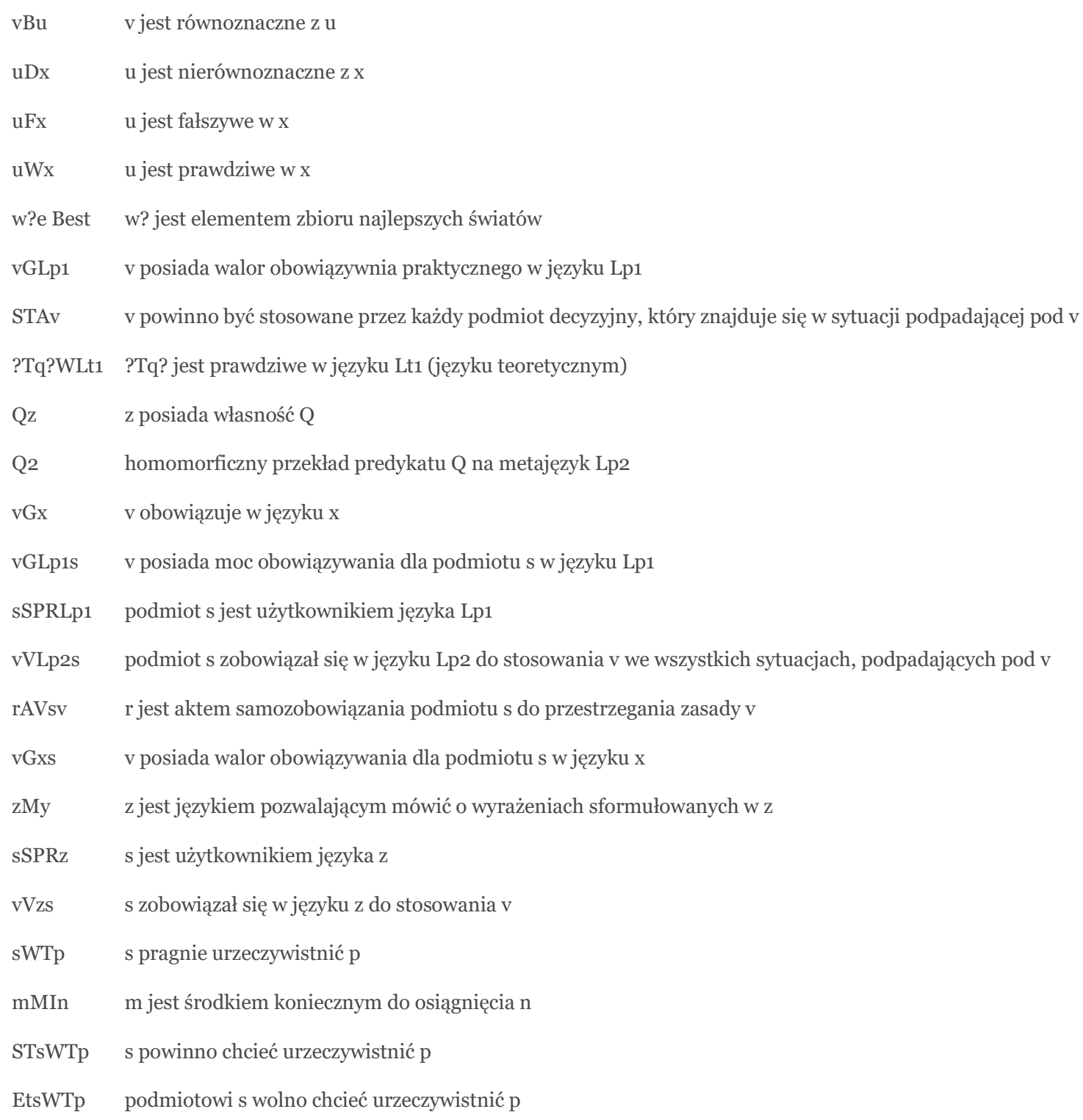

\section{Literatura}

Brink, D.O. (1989). Moral realism and the foundations of ethics. Cambridge, New York, Melbourne: Cambridge University Press.

Frankena, W. (1970). The naturalistic fallacy. Mind, New Series, XLVIII, No. 192, 1939; cyt. za W. Sellars, J. Hospers, Readings in Ethical Theory, Wyd.II, New York: Prentice Hall, Englewood Cliffs ss. 54-62.

Hare, R.M. (1952, 1972). The language of morals. Oxford: Oxford University Press.

Kant. I. (1968). Grundlegung zur Metaphysik der Sitten (1785). W: Gesammelte Schriften, t. IV, Akademie-Ausgabe, Berlin, ss. $385 ? 464$.

Mackie, J.L. (1977). Ethics, Inventing Right and Wrong. Harmondsworth: Penguin Books 1977, nm. Ethik. Auf der Suche nach dem Richtigen und Falschen. Stuttgart.

Moore, G.E. (1960). Principia Ethica (1903), New York: Cambridge University Press.

Morscher, E. (1974). Das Sein-Sollen-Problem logisch betrachtet. Eine Übersicht über den gegenwärtigen Stand der Diskussion?, w: Conceptus 8, nr 25, ss. 5-29. 
Quine, W.V. (1969a). Epistemology naturalized, w: Ontological Relativity and other essays. New York \& London: Columbia University Press, ss. 69-90.

- (1969b). Natural kinds, w: Ontological relativity and other essays. New York \& London: Columbia University Press, ss. 114138.

- (1991). Immanence and Validity, w: Dialectica, t. 45, 2-3, ss. 219-230.

Russell, B. (1966): The Elements of Ethics, w: tenże, Philosophical Essays (1910). London: Allen and Unwin, ss. 13-59.

Schurz, G. (1994). Grenzen rationaler Ethikbegründung. Das Sein-Sollen-Problem aus moderner Sicht, w: Ethik und Sozialwissenschaften 6 (1995), ss. 163-240.

Seel, G. (1977). Struktur und Geltung des wirtschaftlichen Handelns, w: Lehrstücke der praktischen Philosophie und der Aesthetik. Red. K. Bärthlein \& G. Wolandt, Basel \& Stuttgart: Schwabe, ss. 113-189.

- (1983). Ist der praktische Begründungsregress abschliessbar?, w: Der Mensch und die Wissenschaften vom Menschen. Red. G. Frey \& J. Zelger, Innsbruck: Solaris, t. II, ss. 609-619.

- (1989). Sind hypothetische Imperative analytische praktische Sätze?, w: Grundlegung zur Metaphysik der Sitten. Ein kooperativer Kommentar. Red. O. Höffe, Frankfurt/M: Vittorio Klostermann, ss. 148-171.

Warnock, G.J. (1967). Contemporary Moral Philosophy, London: Palgrave Macmillan. Cyt. za: Grewendorf \& Meggle (red.), Seminar: Sprache und Ethik, Frankfurt/M: Suhrkamp, 1974.

* Autor jest profesorem etyki, logiki, estetyki i filozofii praktycznej na Uniwersytecie Berneńskim (Szwajcaria). Artykuł stanowi zaktualizowaną wersję tekstu pt. Wie weit kann man den Naturalismus in der praktischen Philosophie treiben?, którego pierwodruk ukazał się w Grazer Philosophische Studien. Internationale Zeitschrift für Analytische Philosophie, hg. von R. Haller, Vol. 57 ? GA 1999, Amsterdam ? Atlanta, ss. 275-310. Przekładu polskiego dokonano za zgodą autora.

1. Jest zrozumiałe, że do sztucznego języka praktycznego zaliczają się także logiczne reguły zastosowania wyrażeń zawierających operator $S T$. Musi być np. uregulowane to, jak dokonać negacji takich wyrażeń i co taka negacja zmienia. (context)

2. Zobacz tabelę skrótów podaną na końcu artykułu. (context)

3. Nie należy przejmować się tym, że ANIa oraz b dopuszczają formalnie możliwość, że w jakimś innym, odrębnym języku istnieje zdanie równoznaczne $\mathrm{z} v$. Wykazaliśmy bowiem, że równoznaczność zdań sformułowanych na gruncie różnych języków innego typu niż język przez nas założony nie odgrywa roli i można ją pominąć. Jest jednak jasne, że antynaturaliści nie zaakceptowaliby tego, że w jakimkolwiek innym języku teoretycznym występować może zdanie równoznaczne $\mathrm{z} v$. (context)

4. Stanowisko określane przeze mnie mianem ?praktycznego subiektywizmu? ma swoje odpowiedniki w rozmaitych odmianach emotywizmu etycznego i decyzjonizmu etycznego. (context)

5. Sądzę, należy traktować poważnie twierdzenie wielokrotnie stawiane przez Tarskiego, że jego konwencja T stanowi semantyczną formułę prawdy jako zgodności z rzeczywistością. (context)

6. Przyjmując, że dla twierdzeń teoretycznych istnieje dwuwartościowe kryterium ?prawdziwości? i ?fałszywości?. (context)

7. Także naturalizm I stopnia znajduje wyraz w stanowisku powiadającym, że dla wszystkich predykatów praktycznych języka $x$ istniałyby zasady przechodniości uzależniające te predykaty od określonych predykatów teoretycznych. (context)

8. Jest to najczęściej spotykane ujęcie tzw. ?problemu bytu i powinności?. Ostrożniej na ten temat pisze E. Morscher (1974); por. także G. Schurz (1994). (context)

9. Nie chodzi mi tutaj o jakąś historyczną odmianę prądu filozoficznego o nazwie ?pragmatyzm?, lecz o systematyczną charakterystykę pragmatycznego uprawomocniania norm. (context)

10. Nie dotyczy to tzw. miękkiej wersji teorii koherencji, zawierającej elementy fundacjonizmu. (context) 